\title{
Utilização de Desenho Animado como Contexto Gerador de Atividades para o Ensino de Ciências
}

\author{
Use of Cartoon as a Generator Context of Activities for Science \\ Teaching
}

Fabricio Luís Lovato ${ }^{\text {; Lenira Maria Nunes Sepel }}{ }^{2}$

1 Doutor, Instituto Federal de Educação, Ciência e Tecnologia Sul-Riograndense, Campus Visconde da Graça - CaVG, Pelotas, RS, Brasil - fabricio.biotox@ gmail.com / https://orcid.org/0000-0002-8900-0546

2 Doutora, Universidade Federal de Santa Maria, Santa Maria, RS, Brasil - lenirasepel@gmail.com / https://orcid.org/00000001-8372-057X

\author{
Palavras-chave: \\ Desenho Animado; \\ Educação Ambiental; \\ Água.
}

RESUMO: Os desenhos animados constituem a preferência das crianças dentro da grade televisiva. A escola precisa estar inteirada das linguagens da sociedade informatizada e tecnológica em que está inserida, procurando estabelecer junto aos alunos abordagens que apresentem pontos de contato com esse mundo de imagens. A integração dos recursos audiovisuais na sala de aula pode organizar as atividades de ensino e desenvolver no aluno a competência de leitura crítica do mundo. Apresentamos nesse trabalho uma série de atividades relacionadas à Educação Ambiental, em especial ao tema da qualidade da água, desenvolvidas a partir do contexto gerado pelo quarto episódio da segunda temporada do desenho animado Os Simpsons (1990), o qual foi assistido por uma turma do $6^{\circ}$ ano do Ensino Fundamental. Foram realizadas atividades de produção de resumo, discussões em pequenos e em grande grupo, pesquisa textual, leitura de textos informativos e duas atividades investigativas sobre potabilidade e $\mathrm{pH}$ da água. Ao longo de todo o percurso, os alunos sentiram-se motivados para o engajamento nas ações propostas. A metodologia realizada possibilitou aos estudantes a reflexão acerca dos impactos do homem sobre o ambiente, fornecendo meios para que formulassem suas próprias opiniões e argumentos, auxiliando também o seu desenvolvimento nas esferas moral e intelectual.

ABSTRACT: Cartoons are the children's preference within the television grid. The school needs to be aware of the languages of the computerized and technological society in which it is inserted, seeking to establish with the students approaches that present points of contact with this world of images. The integration of audiovisual resources into the classroom can organize teaching activities and develop the student's critical reading competence of the world. In this work, we present a series of activities related to Environmental Education, in particular the theme of water quality, developed from the context generated by the fourth episode of the second season of the cartoon The Simpsons (1990), which was watched by a class of the 6th year of Elementary School. Activities of summary production, discussions in small and large groups, textual research, reading of informative texts and two investigative activities on potability and $\mathrm{pH}$ of water were carried out. Throughout the course, students felt motivated to engage in the proposed actions. The methodology carried out allowed students to reflect on the impacts of man on the environment, providing means for them to formulate their own opinions and arguments, also helping their development in the moral and intellectual spheres. 


\section{INTRODUÇÃO}

A televisão invadiu os espaços educacionais, tornando-se uma "escola paralela" que muitos educadores veem como um desafio. As crianças consideram o conteúdo veiculado pela TV mais relevante do que a escola (OROZCO-GÓMEZ, 1997). Apesar de muitas programações consideradas irrelevantes ou prejudiciais, também há a presença de programas estimulantes para a imaginação, a aprendizagem e a vida - o que deve levar os educadores a assumirem uma posição de mediação entre a TV, a escola e os processos de aprendizado que envolvem os alunos (OROZCO-GÓMEZ, 1997).

A $7^{a}$ edição da pesquisa Kids Experts, promovida pela rede Cartoon Network, realizando entrevistas com crianças do Brasil, Argentina e México, procurou entender como crianças e adolescentes se relacionam com diferentes telas, plataformas e tecnologias. Com a participação de crianças de 7 a 10 anos, e de adolescentes de 13 a 15 anos, a TV foi apontada por $88 \%$ a $99 \%$ dos entrevistados como a plataforma mais acessada em casa, seguida pelo computador, para $78 \%$ a $87 \%$ das crianças e adolescentes (EXAME, 2012). Devido a isso, não é sem razão que a maioria das emissoras abertas de TV destinam parte de sua programação para atender ao público infanto-juvenil, e muitos canais de TV por assinatura veiculam desenhos animados em tempo integral.

A integração dos recursos audiovisuais na sala de aula pode organizar as atividades de ensino e desenvolver no aluno a competência de leitura crítica do mundo, facilitando a compreensão dos conteúdos e o desenvolvimento e a consolidação do processo de ensinoaprendizagem (ARROIO; GIORDAN, 2006). Para Ferrés (1996), a incorporação dos temas televisivos torna o processo de ensino-aprendizagem mais motivador, por permitir que o aluno transforme suas emoções e prazer em reflexão. Partir das emoções geradas pela TV para alcançar o racional e o reflexivo constitui-se então uma utilização adequada do audiovisual no ambiente escolar.

Além de propiciar momentos de entretenimento, os desenhos animados podem tornarse instrumentos valiosos que favorecem a aprendizagem e o desenvolvimento pessoal e profissional (BOSELLI, 2002). Contudo, por parte dos professores persistem dificuldades e incertezas quanto à escolha, reflexão e análise de vídeos utilizados, por não terem noções do alcance, limites e possibilidades destes recursos dentro da sala de aula (ALVES, 2001; CHAMPANGNATTE; NUNES, 2011).

Com essas informações em vista, a utilização dos recursos audiovisuais no processo de ensino-aprendizagem requer que o professor compreenda como poderá relacionar o vídeo aos conteúdos trabalhados, e levar o aluno a perceber que o uso daquele material constitui parte da aula, como um gerador de reflexões e atividades significativas. O professor deve estar 
seguro das metodologias a serem utilizadas e dos seus objetivos, para que esses sejam alcançados.

Um dos principais assuntos a serem trabalhados em Ciências durante o Ensino Fundamental tem a ver com os tópicos de Educação Ambiental. Bornheim (2001) destaca que a relação do homem com a natureza nunca foi tão conflituosa como em nossa época. Os problemas relacionados ao meio ambiente passam a integrar as dimensões social e política do homem, devendo-se buscar suas resoluções aqui e agora.

Entre os assuntos ligados à Educação Ambiental, o da qualidade da água é de fundamental importância. De acordo com o relatório das Nações Unidas Sick Water? - The Central Role of Wastewater Management in Sustanaible Development, de 2010, 2 milhões de toneladas de esgoto e resíduos industriais e agrícolas são despejados em cursos de água do mundo e no mínimo 1,8 milhão de crianças menores de cinco anos morrem todos os anos por doenças relacionadas à água (CORCORAN et al., 2010).

Assim, esse artigo tem como objetivo apresentar uma série de atividades relacionadas à Educação Ambiental, em especial ao tema da qualidade da água, desenvolvidas a partir do contexto gerado por um episódio de desenho animado, com uma turma do $6^{\circ}$ ano do Ensino Fundamental.

\section{METODOLOGIA}

A atividade foi realizada com uma turma de 32 alunos do $6^{\circ}$ ano do Ensino Fundamental, em uma escola da rede privada no município de Santa Maria, RS. A turma era composta por 19 meninos e 13 meninas, com idades variando entre 11 e 12 anos. A realização de todas as atividades ocupou 10 horas-aula, ocorrendo três vezes por semana, nos períodos da disciplina de Ciências.

\section{a) Desenho animado Os Simpsons}

Os alunos assistiram em aula ao quarto episódio da segunda temporada (1990) do desenho animado Os Simpsons, disponibilizado na internet e intitulado "O peixe de três olhos" (título original: "Two Cars in Every Garage and Three Eyes on Every Fish”), com duração de 23 minutos.

\section{b) Produção de resumo}

Após assistirem ao episódio, cada aluno deveria produzir um texto escrito, com 10 linhas, apresentando os principais acontecimentos do desenho. 


\section{c) Discussões em grupo}

Nas duas aulas seguintes, os alunos foram organizados em 8 grupos de 4 participantes, por afinidade (de agora em diante, G1, G2, ... G8). Cada grupo deveria discutir entre seus participantes e entregar uma resposta escrita para cada uma das 9 perguntas a seguir. As perguntas foram escritas no quadro para que todos os alunos as pudessem ler, e foi concedido o tempo de até 8 minutos para a discussão e a escrita de cada resposta.

1) Como parece a qualidade da água no local da pesca? O seu grupo pescaria nesse local?

Para essa pergunta, foi apresentada aos alunos a cena do desenho de Bart e Lisa pescando em uma bela floresta (1'31')).

2) O que pode estar sendo lançado na água?

Foi reapresentada aos alunos a cena da usina nuclear de Springfield despejando seus resíduos no lago onde Bart e Lisa estavam pescando (2'25'’).

3) Por que o peixe pode ter nascido com três olhos? Desenvolvam uma explicação.

4) De que forma as substâncias lançadas nas águas podem afetar a sobrevivência e a qualidade de vida dos organismos aquáticos? Seria possível um peixe nascer com 3 olhos no mundo real?

5) Vocês já ouviram falar em bioindicadores? Tentem criar uma definição para essa palavra. Vamos ver qual grupo chega mais próximo de acertar!

6) As pessoas em geral também lançam contaminantes na água ou apenas as grandes indústrias fazem isso?

7) Pensem em suas próprias casas. Vocês acreditam que possam estar produzindo algo que esteja contaminando as águas?

8) Faça uma avaliação ética da atitude do Senhor Burns com o inspetor de segurança. Teria sido certo o que ele fez?

Para essa pergunta, os alunos foram relembrados do trecho do desenho em que o Sr. Burns tenta subornar o inspetor de segurança, a respeito das irregularidades presentes na usina.

9) Você acredita que no mundo de hoje isso possa ocorrer? Empresas podem colocar seus interesses comerciais à frente do cuidado ambiental?

$\mathrm{Na}$ aula seguinte às discussões, o professor retomou cada questão, discutindo e refletindo coletivamente as respostas apresentadas. 


\section{d) Atividade de pesquisa: Bioindicadores}

Cada aluno deveria realizar (em casa), individualmente, uma pesquisa sobre o que são espécies bioindicadoras da qualidade da água, sua importância e descrever com maior detalhe cinco exemplos escolhidos. Um material escrito deveria ser preparado para entrega ao professor na aula seguinte.

\section{e) Leitura de textos informativos}

$\mathrm{Na}$ aula seguinte, o professor retomou o tópico das espécies bioindicadoras, permitindo que alguns alunos comentassem a respeito do que haviam descoberto em sua pesquisa. A seguir, os grupos reuniram-se novamente e cada um deles recebeu uma cópia dos seguintes textos:

a) Poluição provoca o aparecimento de caranguejos 'mutantes' no litoral de SP, disponível em: <goo.gl/pUo3kh>;

b) Feto de raia com duas cabeças encontrada na Austrália, disponível em: <goo.gl/L3krKE> e traduzido pelo professor;

c) Passado e tragédia, disponível em: 〈goo.gl/b4yHy9>.

Os alunos deveriam ler em seus grupos cada um dos textos. A seguir, o professor realizou uma conversa informal sobre o conteúdo de cada notícia e como elas se relacionavam com os temas em estudo na aula.

\section{f) Atividade investigativa 1: Potabilidade da água}

Em uma atividade prática realizada no laboratório de Ciências da escola, inspirada no trabalho de Nicoletti (2013), utilizou-se 7 garrafas de plástico (Figura 1), com os seguintes conteúdos: GARRAFA 1: Água com terra; GARRAFA 2: Água com álcool; GARRAFA 3: Água retirada de um algário; GARRAFA 4: Água retirada de um açude; GARRAFA 5: Água potável (obtida da torneira); GARRAFA 6: Água com vinagre; GARRAFA 7: Água com detergente. 


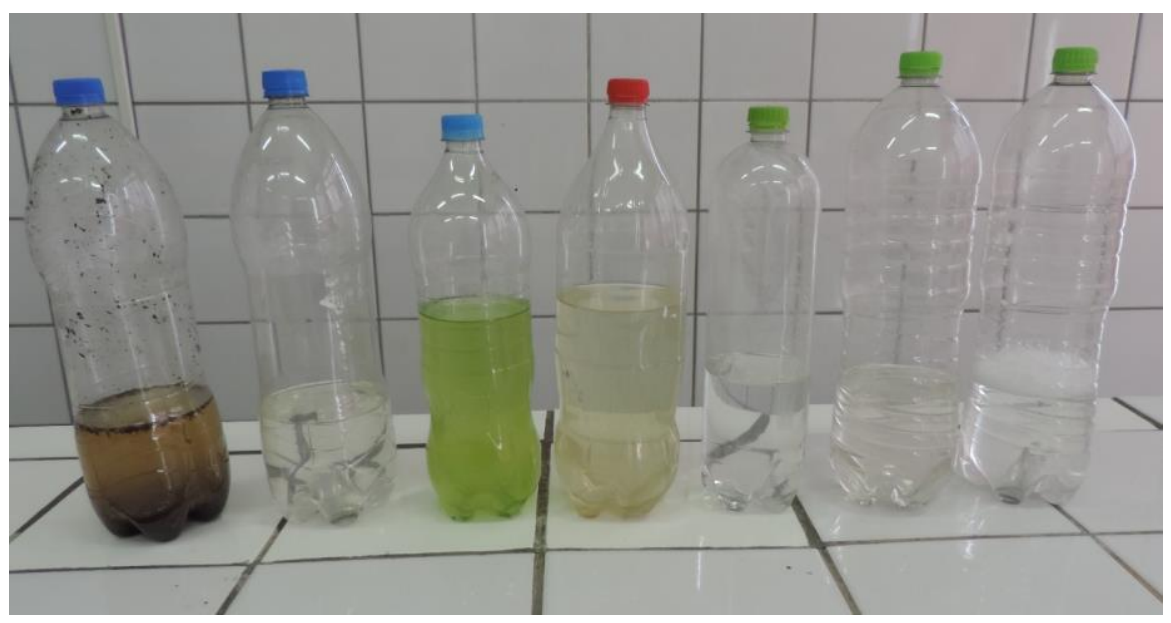

Figura 1 - Garrafas contendo água com diferentes elementos.

Fonte: Autores.

Desconhecendo os conteúdos de cada recipiente, cada grupo deveria observar as amostras, sem tocá-las, e elaborar respostas escritas para as seguintes questões: a) Conteúdo da amostra (“'O que cada garrafa contém?”); b) Origem da amostra (“Onde essa amostra pode ter sido obtida?"); c) Potabilidade ("Vocês beberiam essa água?"); d) Tratamento da amostra (“Essa água poderia ser purificada? Como?”). As respostas deveriam ser apresentadas com argumentos, dentro do possível.

Em uma segunda etapa da atividade, os alunos poderiam manusear as amostras, mas sem abrir os recipientes, e a seguir, apontar em quais das respostas anteriores alterariam suas opiniões. Em uma última etapa, os alunos poderiam abrir os recipientes e cheirar as amostras, novamente respondendo às mesmas perguntas. Foi explicado que não é seguro inspirar amostras de conteúdo ou origem desconhecida, mas que no caso, o professor conhecia a origem e o conteúdo de cada recipiente.

\section{g) Atividade investigativa 2: pH da água}

Os grupos foram novamente apresentados a amostras, mas agora informados do seu conteúdo. Em copos de plástico transparentes, colocou-se água com diversos conteúdos: COPO 1: vinagre branco; COPO 2: água sanitária; COPO 3: detergente; COPO 4: suco de limão; COPO 5: bicarbonato de sódio; COPO 6: álcool; COPO 7: soda cáustica; e COPO 8: leite. A seguir, extrato de repolho roxo (o qual age como indicador natural de acidez e basicidade), preparado segundo GEPEQ (1995), foi adicionado a cada uma das amostras. Os alunos deveriam relatar as mudanças de cores observadas e pensar em alguma explicação para o fenômeno. Na aula seguinte, os alunos receberam uma explicação, adequada ao seu nível de compreensão, sobre o conceito de $\mathrm{pH}$, e como esse se relaciona à qualidade da água. 
Ensino, Saúde e Ambiente - V14 (1), pp. 01-27, ABR. 2021

\section{RESULTADOS E DISCUSSÃO}

\section{a) Desenho animado Os Simpsons}

Os Simpsons é um seriado animado produzido por Matt Groening, desde 1989. Ele apresenta o cotidiano de uma família americana, demonstrando em forma de sátira situações do cotidiano e tocando em temas polêmicos da sociedade e do modo de vida dos EUA. Tais fatos possibilitam que a série seja uma ferramenta de apoio às aulas de Ciências, propiciando discussões entre os estudantes (HALPERN, 2008).

A escolha do desenho e do episódio específico deveu-se a vários fatores: a) antes do início das atividades, os alunos foram questionados informalmente e todos responderam que conheciam o desenho e seus personagens, com grande parte dos alunos ainda assistindo episódios esporádica ou regularmente; b) o episódio escolhido apresentava temáticas ligadas aos impactos causados pelo homem sobre a natureza; c) o desenho possibilitava a discussão de conceitos, valores e atitudes ligados à preservação ambiental e vida em sociedade; e d) apresentava duração apropriada, pois segundo Betti (2001), vídeos curtos são mais adequados ao trabalho em sala de aula.

\section{b) Produção de resumo}

Conforme Rosa (2000), todo vídeo apresentado traz a necessidade de um trabalho de elaboração em cima do que foi assistido. Após a apresentação, o professor deve trabalhar com seus alunos a compreensão do que foi visto. A compreensão/interpretação do material audiovisual exibido pode utilizar-se de diferentes estratégias, como debate, redação e dramatização (FERRÉS, 1996).

Em nosso estudo, optamos por oportunizar o reforço da habilidade escrita. Morán (1995) aponta que enquanto a linguagem audiovisual permite o desenvolvimento de múltiplas atitudes perceptivas, ao solicitar constantemente a imaginação e reinvestir a afetividade com um papel de mediação primordial no mundo, a linguagem escrita permite maior desenvolvimento do rigor, da organização e da análise lógica.

Dos 32 alunos, 21 realizaram a entrega do resumo proposto. Da estipulação de 10 linhas, ocorreram algumas variações, para mais ou menos, conforme apresentado na Tabela 1. 
Ensino, Saúde e Ambiente - V14 (1), pp. 01-27, ABR. 2021

Tabela 1 - Relação entre o número de alunos e de linhas das redações.

\begin{tabular}{cc}
\hline Número de linhas & Número de alunos \\
\hline $6-8$ & $5(23,81 \%)$ \\
$9-11$ & $6(28,57 \%)$ \\
$12-15$ & $6(28,57 \%)$ \\
Acima de 15 linhas & $4(19,05 \%)$
\end{tabular}

Fonte: Autores

Um dos objetivos do resumo era observar quais aspectos do desenho apresentado foram mais marcantes para os alunos e considerados importantes para sua apresentação no texto. A Tabela 2 apresenta os principais momentos da sequência do desenho conforme destacados pelos alunos e a quantidade de alunos que relacionou tal acontecimento.

Tabela 2 - Principais acontecimentos do desenho, relatados nas redações dos alunos.

\begin{tabular}{lc}
\multicolumn{1}{c}{ Acontecimento do desenho } & Número de alunos \\
\hline Bart e Lisa pescando em um rio & $21(100 \%)$ \\
Usina nuclear contaminando o rio & $14(66,67 \%)$ \\
Pesca de peixe de três olhos & $21(100 \%)$ \\
Conversa das crianças com repórter & $9(42,85 \%)$ \\
Notícia publicada no jornal & $11(52,39 \%)$ \\
Vistoria na usina & $9(42,85 \%)$ \\
Tentativa de suborno pelo Sr. Burns & $4(19,05 \%)$ \\
Candidatura do Sr. Burns a governador & $12(57,14 \%)$ \\
Peixe de três olhos servido no jantar & $7(33,33 \%)$ \\
Sr. Burns não consegue comer o peixe & $6(28,57 \%)$ \\
Sr. Burns perde a eleição & $9(42,85 \%)$
\end{tabular}

Fonte: Autores.

Os dois principais acontecimentos narrados unanimemente pelos alunos foram o fato de Bart e Lisa estarem pescando em um rio e encontrarem um peixe de três olhos. A maior parte dos alunos (14) citou a contaminação do rio pela usina nuclear, a publicação da notícia do peixe no jornal (11) e a candidatura do Sr. Burns (12). Surpreendentemente, o acontecimento menos lembrado pelos alunos (4) foi a tentativa de suborno do Sr. Burns aos inspetores, embora um maior número (9) escreveu sobre a vistoria na usina. 


\section{c) Discussões em grupo}

As discussões em grupo devem envolver um número suficientemente grande de alunos para que surja uma diversidade de opiniões, mas também deve ser suficientemente pequeno para que todos os participantes tenham a oportunidade de expressarem seus posicionamentos (SLAVIN, 1994). Em nosso caso, consideramos o número de 4 participantes por grupo como apropriado.

Em relação à primeira pergunta, a respeito da qualidade da água no local de pesca, a maioria dos grupos descreveu o ambiente positivamente, como uma "floresta normal" (G1), “conservado com muita natureza e ar puro" (G8), “com animais" (G2) e "agradável” (G6). Apenas um dos grupos (G4) descreveu negativamente o cenário ("um rio muito poluído com residuos tóxicos"), o que se depreende que interpretaram a questão a partir do contexto posterior do desenho, e não da imagem destacada.

Quatro grupos (G3, G6, G7 e G8) afirmaram que pescariam no local, enquanto os grupos restantes afirmaram que não, pois o "rio pode estar poluido" (G5) e que "a água pode conter substâncias químicas" (G2). Na discussão posterior, pudemos destacar junto aos alunos que, apesar de um ambiente natural parecer belo e bem conservado, deve-se evitar o consumo de sua água, a pesca ou outras atividades recreativas, devido à possibilidade da presença de substâncias químicas tóxicas ou agentes patogênicos invisíveis a olho nu.

$\mathrm{Na}$ segunda pergunta, um dos grupos não respondeu (G1), enquanto os demais afirmaram que a usina estava lançando "resíduos tóxicos" (G4 e G6), "substâncias químicas" (G2 e G5) ou "lixo tóxico" (G3, G7 e G8). Nenhum dos grupos destacou as palavras radiação ou radioatividade nessa pergunta, embora essa tenha sido destacada no desenho e seja o principal resíduo de uma usina nuclear.

Na terceira pergunta, G1 e G3 destacaram que a "radiação” causa mudanças nos seres vivos. Os outros grupos se referiram aos "resíduos tóxicos" (G6), "substâncias químicas" (G2, G5 e G8) e "lixo tóxico” (G7) como agentes prejudiciais e causadores de mudanças nos seres vivos. Dois grupos (G4 e G8) utilizaram a palavra "mutação" como o mecanismo responsável pela mudança no peixe.

Na quarta pergunta, G1, G3 e G8 afirmaram que as substâncias tóxicas levam à morte da vida aquática. Outros grupos afirmaram que, além de morte, os seres vivos aquáticos podem "ficar danificados" (G2) ou "sofrer mutações" (G4). G6 afirmou que as substâncias tóxicas levam a um "defeito que acontece dentro do ovo" e G8 afirmou que enquanto ocorreria morte da vida marinha, aqueles que ainda estavam dentro dos ovos "teriam se adapitado [sic]”. Quanto à possibilidade da existência de um peixe de três olhos na vida real, 
metade dos grupos (G2, G4, G5 e G7) afirmou a possibilidade, enquanto os demais declararam que tal acontecimento é impossível.

Sobre a quinta pergunta, todos os grupos declararam que jamais haviam escutado sobre bioindicadores. Em suas tentativas de construir uma definição por meio de palpites, nenhum grupo chegou próximo à resposta apropriada. As respostas foram diversificadas, como "um grupo de Biólogos" (G2), um “equipamento para melhorar os animais" (G4) e "tipo de programa para ajudar e combater os rios e lagos sujos" (G1). Os outros grupos apresentaram respostas evasivas ou insuficientes, como é "algo que indica algo" (G5) ou "eles indicam coisas sobre a Biosfera" (G3).

Na sexta pergunta, todos os grupos afirmaram que as pessoas em geral e não apenas as grandes indústrias contaminam os corpos d'água. G1 afirmou que isso acontece "não só nos EUA, mas em outros lugares do mundo". Foram citados como exemplos dessa poluição os “esgotos" (G3), o "lixo" (G3, G4 e G8) e "carros e todos automoveis [sic]" (G8).

Ironicamente, apesar de todos os grupos afirmarem que as pessoas poluem a água, na sétima pergunta, ao serem questionados sobre suas próprias residências, metade dos grupos (G2, G3, G7 e G8) afirmou que não produzem qualquer resíduo que poderia estar contaminando as águas. Os demais grupos responderam de forma positiva. G1 citou como exemplo os produtos "para poder limpar a casa, roupas, etc.” (G1), enquanto G6 respondeu que "quando lavamos a roupa tem um cano no tanque que a agua vai até os rios e dai afeta a água, pois a água vai suja por causa das roupas" e G4 lembrou sobre o "esgoto" que vem de nossas residências (G4). G5 afirmou ainda que "quase todos nós já jogamos azeite fora ou outros produtos".

Ao retomarmos essa questão na discussão posterior, todos os alunos puderam se dar conta de que realmente produzimos diariamente resíduos que serão lançados no esgoto e se encaminharão para os rios e mares. O que podemos fazer é adotar medidas sustentáveis, que reduzam essa poluição, como não jogar lixo em locais públicos, diminuir nosso consumo de plástico, reciclarmos o que for possível, realizarmos um descarte adequado de óleo de cozinha e produtos de limpeza etc.

$\mathrm{Na}$ oitava pergunta, todos os grupos afirmaram que a atitude do Sr. Burns foi eticamente errada, ao tentar subornar o inspetor de segurança para que não fosse punido quanto às irregularidades em sua usina. Uma das respostas mais completas foi a de G8, que assinalou que "é muito errado fazer suborno e pior ainda aceitar, pois o inspetor está ali para a saúde e segurança pública e ele deve sofrer as consequências do que fez."

$\mathrm{Na}$ última questão, todos os grupos mais uma vez afirmaram que em nossos dias, interesses comerciais e financeiros são colocados como prioridade em relação aos cuidados 
com o meio ambiente. Eles afirmaram que muitas empresas e pessoas "só pensam em si mesmas" (G6), "estão mais interessadas em ganhar dinheiro” (G7), "não estão nem aí para a saúde pública e ambiental" (G8) e "não pensam nas consequências que isso pode trazer a natureza” (G4).

É importante que além do conhecimento científico, temas éticos e sociais sejam levantados para a discussão com os alunos. Não se pode duvidar que as questões relativas à ética e de responsabilidade social inevitavelmente fazem parte do ensino de Ciências, deixando professores expostos constantemente ao tratamento de valores globais diversos. $\mathrm{O}$ ensino de Ciências deve envolver um processo em que todo o campo de ação do desenvolvimento pedagógico entre alunos, professores, conteúdos e metodologias apresente tendências éticas nas suas relações (RAZERA; NARDI, 2006).

A trama do desenho funcionou como tema gerador de discussões, propiciando a fixação dos conteúdos e levando à reflexão das implicações sociais e ambientais das decisões tomadas na vida cotidiana, contribuindo dessa forma para a formação da criticidade dos alunos. O episódio exibido também favoreceu a discussão da dimensão moral: as atitudes dos personagens, como as do Sr. Burns e do inspetor de segurança, conduziram à troca de ideias sobre como agir em determinadas situações e a importância de mantermos uma ética elevada e refletirmos na importância dos cuidados com o meio ambiente acima de interesses políticos e comerciais egoístas.

\section{d) Atividade de pesquisa: Bioindicadores}

$\mathrm{Na}$ atividade seguinte, cada aluno deveria realizar e entregar uma pesquisa sobre a temática das espécies bioindicadoras da qualidade da água, pesquisando sobre sua definição, importância e descrevendo com maior detalhe cinco exemplos escolhidos. Apesar de já prevista no cronograma das atividades, tal pesquisa justificou-se também devido a nenhum dos grupos ter conseguido alcançar uma definição apropriada, levando-os à curiosidade sobre o seu significado.

Espécies bioindicadoras são espécies biológicas que apresentam pequena tolerância a variações ambientais e, quando presentes em um determinado local, revelam um conjunto de condições particulares daquele ambiente. Rápidas mudanças do ambiente provocadas pelo homem causam flutuações populacionais nos organismos, por isso, comunidades biológicas com a presença de poluentes na água sofrem alterações em sua densidade e riqueza (PIMENTA et al., 2015).

A pesquisa configura-se como uma ferramenta de aprendizado, tornando os alunos parceiros do professor nessa construção, e não mais meros observadores passivos do processo. 
O aluno é capaz então de criar novas relações entre os conhecimentos que já possuía e os que está encontrando durante suas pesquisas, desenvolvendo competências como a discussão e aceitação de diferentes pontos de vista, a crítica de informações, o entendimento da organização do pensamento científico e a utilização dos recursos tecnológicos (GUIMARÃES; GONÇALVES, 2013).

A Internet oferece diversas possibilidades de pesquisa, tanto para os professores como para os alunos, dentro e fora da sala de aula. Ao se digitar duas ou três palavras em um site de busca, inúmeros resultados aparecem, para qualquer assunto. Como essa facilidade acaba trazendo também alguns problemas, é importante sensibilizar o aluno antes, para que se alcance o objetivo que se quer conseguir neste momento (MORÁN, 1999).

\section{e) Leitura de textos informativos}

É importante ressaltar que desenhos animados não têm a intenção de representar conceitos e técnicas científicas de forma precisa ou realista. Como Halpern (2008, p. 173) explica, "os desenhos animados podem ajudar a entender e a apreciar a ciência, mas eles, muitas vezes exageram ou distorcem as propriedades da natureza.” Uma das questões que suscitou a curiosidade dos alunos ao assistirem ao desenho e realizarem as discussões em grupo foi sobre os reais efeitos que as substâncias químicas podem desencadear sobre os seres vivos. Isso se deve em parte porque as principais referências que os alunos têm sobre DNA, leis da hereditariedade e mutações vêm de desenhos e filmes de ficção científica, e porque ainda não foram apresentados formalmente a tais conceitos no ambiente escolar.

A leitura dos textos "Poluição provoca o aparecimento de caranguejos 'mutantes' no litoral de SP" e "Feto de raia com duas cabeças encontrado na Austrália" teve por objetivo apresentar aos alunos alguns dos efeitos e deformações provocados pela poluição sobre a vida marinha. Os alunos acharam surpreendente que o primeiro caso tenha ocorrido em nosso próprio país. O professor também discutiu com os alunos sobre a razoabilidade de se alimentar com seres contaminados com alto teor de poluentes.

O terceiro texto, "Passado e tragédia", teve por objetivo discorrer sobre o famoso caso do desastre ambiental de Minamata, no Japão, onde centenas de pessoas foram contaminadas com mercúrio, devido ao despejo irregular de resíduos por uma indústria nas águas. Diversos sinais neurológicos começaram a aparecer na população, como distúrbios sensoriais nas mãos e pés, problemas de visão e audição, fraqueza e, nos casos extremos, paralisia e morte. Assim, os alunos puderam perceber que não apenas outras formas de vida podem ser afetadas, mas a qualidade da água está relacionada à própria saúde e sobrevivência de nossa espécie. 
Ensino, Saúde e Ambiente - V14 (1), pp. 01-27, ABR. 2021

A leitura de textos de divulgação científica contribui para a formação do aluno, permitindo que este aumente o seu vocabulário e conhecimentos. $\mathrm{O}$ trabalho com esses textos possibilita as discussões entre professor e alunos sobre questões sociais atuais, enriquecendo a aula (ROCHA, 2012). Ao utilizar em sala de aula reportagens que abordam conceitos científicos, o professor deve escolher o momento adequado para a sua inserção, tendo como referenciais o conteúdo, a linguagem, o tipo de texto, o aluno a que se destina e, principalmente, os objetivos que pretende alcançar com a atividade (MELO; HOSOUME, 2003).

\section{f) Atividade investigativa 1: Potabilidade da água}

Os alunos ficaram bastante entusiasmados com a atividade prática de investigação, a qual possibilitou intensa troca de ideias entre eles sobre as questões apresentadas. O objetivo dessa aula era que os alunos executassem suas habilidades de observação, dedução e argumentação. Na primeira etapa, os alunos deveriam chegar a uma resposta baseados apenas na percepção visual. Em relação à primeira amostra, todos os grupos deduziram corretamente a presença de "terra", "barro" ou "sujeiras" na água. Além de citar o aspecto de coloração, um dos grupos (G8), ao perceber a presença de sujeiras na superfície da água, incorporou ainda em sua explicação um conceito aprendido previamente nas aulas de Ciências: "Água com terra. Porque ela flutua (menos densa que a água) e porque ela está marrom."

Em relação à segunda amostra, as respostas foram variadas. Alguns grupos afirmaram ser álcool, baseados na transparência (G1, G3, G8), embora tal explicação seja insuficiente para excluir outras possibilidades, como a própria água (como sugeriu G6). Mas além da coloração, outros grupos assinalaram que puderam sentir o odor da amostra ao se aproximar dela, levando-os à conclusão de que era álcool (G2 e G4), embora o odor tenha confundido G7, levando-o à resposta de que a amostra continha vinagre.

Na terceira amostra, a presença de uma coloração esverdeada levou à uma maior divergência de respostas: lodo da piscina (G1), refrigerante (G2 e G3), suco (G4, G5), água com corante (G5, G6 e G8) e detergente (G7). Nenhum dos grupos apontou a resposta correta.

Na quarta amostra, a observação atenta da maior parte dos grupos os levou a perceber a presença de grãos de areia no fundo da garrafa (G1, G2, G3, G7 e G8). Uma observação superficial da coloração amarelada da amostra levou também às respostas de vinagre (G4 e G5) e óleo (G6).

Em relação à quinta amostra, a maioria dos grupos indicou conter apenas água (G1, G3, G4, G5, G6 e G8). Um dos grupos indicou que "parece ser vinagre” (G2) e G7 indicou ser álcool, por causa do cheiro (apesar de a amostra não possuir cheiro). 
Ensino, Saúde e Ambiente - V14 (1), pp. 01-27, ABR. 2021

Na sexta amostra, as respostas foram diversificadas. G1 e G2 não apresentaram resposta. G3 e G4 indicaram ser alvex ${ }^{\circledR} / a ́ g u a$ sanitária por causa da coloração, G7 por causa do cheiro e G5 e G8 não apresentaram argumentos. G6 indicou ser álcool (poderia ter havido uma confusão por causa do cheiro do vinagre).

$\mathrm{Na}$ última amostra, a presença de espuma na superfície da água era claramente visível. Por isso, as respostas foram bastante relacionadas entre si: sabão (G1, G3, G4, G5, G6, G7 e G8), produto de limpeza (G2) e detergente (G5).

As respostas à segunda pergunta (origem da amostra) estão apresentadas no Quadro 1. As deduções dos alunos para a pergunta dependeram diretamente das respostas fornecidas à primeira questão.

Quadro 1 - Respostas à Pergunta 2.

\begin{tabular}{|c|c|c|c|c|c|c|c|}
\hline \multicolumn{8}{|c|}{ PERGUNTA 2: Onde a amostra foi obtida? } \\
\hline & $\begin{array}{c}\text { ÁGUA + } \\
\text { TERRA }\end{array}$ & $\begin{array}{l}\text { ÁGUA + } \\
\text { ÁLCOOL }\end{array}$ & $\begin{array}{l}\text { ÁGUA DE } \\
\text { ALGÁRIO }\end{array}$ & $\begin{array}{c}\text { ÁGUA DE } \\
\text { UM AÇUDE }\end{array}$ & $\begin{array}{c}\text { ÁGUA } \\
\text { POTÁVEL } \\
\text { (TORNEIRA) }\end{array}$ & $\begin{array}{c}\text { ÁGUA + } \\
\text { VINAGRE }\end{array}$ & $\begin{array}{c}\text { ÁGUA + } \\
\text { DETERGENTE }\end{array}$ \\
\hline GRUPO 1 & & & & $\begin{array}{l}\text { "Do mar, que } \\
\text { tem areia, ou } \\
\text { de outra coisa } \\
\text { que tenha areia, } \\
\text { tipo um } \\
\text { parquinho." }\end{array}$ & $\begin{array}{l}\text { "Ela veio da } \\
\text { torneira." }\end{array}$ & & \\
\hline$\overline{\text { GRUPO } 2}$ & $\begin{array}{l}\text { "Parece que é a } \\
\text { água de um } \\
\text { lago, porque } \\
\text { muitos lagos } \\
\text { contém essa } \\
\text { sujeira." }\end{array}$ & $\begin{array}{l}\text { "Eles podem } \\
\text { ter comprado } \\
\text { de alguma } \\
\text { fábrica ou eles } \\
\text { podem fazer o } \\
\text { próprio alcool." }\end{array}$ & $\begin{array}{l}\text { "Se for fanta } \\
\text { maça verde, ela } \\
\text { veio da Coca- } \\
\text { Cola." }\end{array}$ & $\begin{array}{l}\text { "A areia parece } \\
\text { ser de praia." }\end{array}$ & $\begin{array}{l}\text { "Da fabrica de } \\
\text { vinagre." }\end{array}$ & & \\
\hline GRUPO 3 & $\begin{array}{lr}\text { "da } & \text { terra } \\
\text { porque } & \text { esta } \\
\text { suja de terra." }\end{array}$ & "do mercado." & "do mercado." & "do mar." & "de um poço." & "do mercado." & $\begin{array}{ll}\text { "misturou água } \\
\text { com sabão." }\end{array}$ \\
\hline GRUPO 4 & $\begin{array}{l}\text { "de alguma } \\
\text { barragem." }\end{array}$ & $\begin{array}{ll}\text { "sairia } & \text { de } \\
\text { alguma } & \\
\text { fabrica." } & \end{array}$ & & $\begin{array}{ll}\text { "sairia } & \text { de } \\
\text { alguma } & \\
\text { fabrica." } & \end{array}$ & $\begin{array}{ll}\text { "surge } & \text { da } \\
\text { nuvem." } & \end{array}$ & & $\begin{array}{l}\text { "sairia de alguma } \\
\text { fabrica." }\end{array}$ \\
\hline GRUPO 5 & $\begin{array}{ll}\text { "de } & \text { algum } \\
\text { lugar } & \text { onde a } \\
\text { terra } & \text { e agua } \\
\text { suja." } & \end{array}$ & $\begin{array}{l}\text { "Da fábrica de } \\
\text { álcool." }\end{array}$ & $\begin{array}{l}\text { "De uma fruta } \\
\text { ou substância." }\end{array}$ & "da uva." & $\begin{array}{l}\text { "de rios, mares, } \\
\text { lagos." }\end{array}$ & $\begin{array}{l}\text { "Da fábrica de } \\
\text { alvex." }\end{array}$ & $\begin{array}{l}\text { "da mistura da } \\
\text { água com sabão." }\end{array}$ \\
\hline GRUPO 6 & "Do lamaçal." & $\begin{array}{l}\text { "Do rio, da } \\
\text { torneira, etc..." }\end{array}$ & $\begin{array}{l}\text { "Da casa } \\
\text { professor." }\end{array}$ & "Da rua." & "Da torneira." & "Da farmácia." & $\begin{array}{ll}\text { "De } & \text { um } \\
\text { experimento." } & \end{array}$ \\
\hline $\begin{array}{l}\text { GRUPO } 7 \\
\end{array}$ & $\begin{array}{l}\text { "Do chão, } \\
\text { porque é terra } \\
\text { com água." }\end{array}$ & $\begin{array}{lr}\text { "Vem de } & \text { uma } \\
\text { planta. } & \text { Um } \\
\text { exemplo tem o } \\
\text { vinagre } & \text { de } \\
\text { maçã." } & \end{array}$ & $\begin{array}{l}\text { "do mercado } \\
\text { porque está nas } \\
\text { prateleiras." }\end{array}$ & "Pela praia." & "da araucaria." & $\begin{array}{l}\text { "fabrica porque } \\
\text { eles fabricam." }\end{array}$ & \\
\hline GRUPO 8 & "Da terra." & $\begin{array}{l}\text { "Do mercado } \\
\text { ou de casa. } \\
\text { Porque álcool } \\
\text { se encontra } \\
\text { nesses } \\
\text { lugares." }\end{array}$ & $\begin{array}{l}\text { "Dos } \\
\text { produtos." }\end{array}$ & $\begin{array}{l}\text { "Da praia. } \\
\text { Porque ela é } \\
\text { encontrada no } \\
\text { chão da praia." }\end{array}$ & $\begin{array}{l}\text { "Dos oceanos. } \\
\text { Da torneira. Pq é } \\
\text { de onde a água } \\
\text { vem." }\end{array}$ & $\begin{array}{l}\text { "Do mercado } \\
\text { de lavagem." }\end{array}$ & $\begin{array}{l}\text { "Do mercado } \\
\text { (detergente). } \\
\text { Porque é onde } \\
\text { vendem as } \\
\text { mercadorias." }\end{array}$ \\
\hline
\end{tabular}


Ao observarmos o Quadro 2, referente à pergunta 3 (potabilidade da amostra), percebemos que as respostas também foram diversificadas. Em relação à primeira amostra, G1 não respondeu, enquanto $\mathrm{G} 4$, para o qual a amostra continha água obtida de alguma barragem, foi o único grupo que respondeu de forma afirmativa. G6 forneceu uma condicional para essa pergunta: "só se nós purificarmos".

Em relação à segunda amostra, G1 não respondeu. G6 (para quem a amostra continha apenas água) e G7 (para quem a amostra continha vinagre) afirmaram que beberiam. Os demais grupos, para os quais a amostra continha álcool, responderam de forma negativa.

Em relação à terceira amostra, as respostas também foram diversificadas, por causa das diferentes interpretações sobre o seu conteúdo. Assim, G2, G3, G4 e G8 responderam de forma positiva, enquanto os demais grupos responderam de forma negativa.

Quanto à quarta amostra, apenas G7 (para o qual havia areia no recipiente) respondeu de forma positiva, desde que a água passasse pela fervura. As demais justificativas para a resposta negativa foram diversas. G1 indicou a presença de bactérias na água, G3 indicou que essa água era salgada, G6 indicou que não se deve ingerir óleo, enquanto G8 indicou que areia não faz bem para a saúde.

Em relação à quinta amostra, G1, G3, G4, G5, G6 e G8 responderam de forma positiva. G2 indicou o seu uso como tempero (devido à sua interpretação da amostra conter vinagre), enquanto G7 respondeu de forma negativa (devido à sua interpretação da amostra conter álcool).

Quanto à sexta amostra, G1 e G2 não responderam, enquanto G3, G5, G6, G7 e G8 afirmaram que não beberiam. G4 respondeu que beberia, apesar de afirmar na primeira pergunta que a amostra continha água sanitária. Postulamos que aqui possa ter ocorrido alguma confusão do grupo em relação à amostra da questão. Em relação à última amostra, G1 e G2 mais uma vez não responderam, enquanto todos os demais grupos responderam de forma negativa. 
Ensino, Saúde e Ambiente - V14 (1), pp. 01-27, ABR. 2021

Quadro 2 - Respostas à Pergunta 3.

\begin{tabular}{|c|c|c|c|c|c|c|c|}
\hline \multicolumn{8}{|c|}{ PERGUNTA 3: Vocês beberiam essa água? } \\
\hline & $\begin{array}{l}\text { ÁGUA + } \\
\text { TERRA }\end{array}$ & $\begin{array}{l}\text { ÁGUA + } \\
\text { ÁLCOOL }\end{array}$ & $\begin{array}{l}\text { ÁGUA DE } \\
\text { ALGÁRIO }\end{array}$ & $\begin{array}{c}\text { ÁGUA DE } \\
\text { UM AÇUDE }\end{array}$ & $\begin{array}{c}\text { ÁGUA } \\
\text { POTÁVEL } \\
\text { (TORNEIRA) }\end{array}$ & $\begin{array}{c}\text { ÁGUA + } \\
\text { VINAGRE }\end{array}$ & $\begin{array}{c}\text { ÁGUA + } \\
\text { DETERGENTE }\end{array}$ \\
\hline GRUPO 1 & & & $\begin{array}{l}\text { "não, porque é } \\
\text { suja." }\end{array}$ & $\begin{array}{l}\text { "Não, porque } \\
\text { na areia tem } \\
\text { bactérias então } \\
\text { quando ela se } \\
\text { mistura com a } \\
\text { água, a água } \\
\text { não pode ser } \\
\text { tomada." }\end{array}$ & $\begin{array}{l}\text { "ela pode ser } \\
\text { consumida." }\end{array}$ & & \\
\hline GRUPO 2 & $\begin{array}{lr}\text { "Não dá } & \text { para } \\
\text { beber, } & \text { pois } \\
\text { parece } & \text { ter } \\
\text { muitas } & \\
\text { bactérias } & \text { que } \\
\text { podem causar } \\
\text { doenças." }\end{array}$ & $\begin{array}{l}\text { "Não pode, } \\
\text { pois ele tem } \\
\text { substâncias } \\
\text { diferentes." }\end{array}$ & $\begin{array}{l}\text { "Da para } \\
\text { beber." }\end{array}$ & $\begin{array}{l}\text { "Não da para } \\
\text { beber." }\end{array}$ & $\begin{array}{l}\text { "Da para usar } \\
\text { como tempeiro." }\end{array}$ & & \\
\hline GRUPO 3 & $\begin{array}{l}\text { "não porque } \\
\text { esta suja." }\end{array}$ & $\begin{array}{l}\text { "não podemos } \\
\text { beber." }\end{array}$ & "podemos." & $\begin{array}{l}\text { "não, pois é } \\
\text { salgada." }\end{array}$ & "é potável." & $\begin{array}{ll}\text { "não } & \text { é } \\
\text { potável." } & \end{array}$ & "não é potável." \\
\hline GRUPO 4 & "Sim tomaria." & "Não tomaria." & "Beberia." & "Não beberia." & "tomaria" & "Sim tomaria." & "Não beberia." \\
\hline GRUPO 5 & "Não pode" & $\begin{array}{l}\text { "Não podemos } \\
\text { beber, faz mal } \\
\text { pra saúde." }\end{array}$ & $\begin{array}{l}\text { "Não dá pra } \\
\text { beber mas } \text { se } \\
\text { for o suco } \\
\text { pode." }\end{array}$ & $\begin{array}{l}\text { "não pode ser } \\
\text { consumida" }\end{array}$ & $\begin{array}{ll}\text { "pode } & \text { ser } \\
\text { consumida" } & \end{array}$ & $\begin{array}{l}\text { "não pode ser } \\
\text { consumida" }\end{array}$ & $\begin{array}{l}\text { "não pode } \\
\text { consumido" }\end{array}$ \\
\hline GRUPO 6 & $\begin{array}{l}\text { "Não, só se nós } \\
\text { purificarmos." }\end{array}$ & $\begin{array}{l}\text { "Esta } \\
\text { purificada." }\end{array}$ & $\begin{array}{l}\text { "Não. Por } \\
\text { causa da cor" }\end{array}$ & $\begin{array}{l}\text { "Não, pois } \\
\text { aquela água } \\
\text { tem óleo que } \\
\text { não é bom para } \\
\text { o consumo" }\end{array}$ & "Esta purificada" & $\begin{array}{l}\text { "não. Pois } \\
\text { sabão } \\
\text { xampu" }\end{array}$ & $\begin{array}{lr}\text { "Negativo. } & \text { Pois } \\
\text { tem aúde } & \text { que } \\
\text { não é bom para } \\
\text { consumo." }\end{array}$ \\
\hline GRUPO 7 & $\begin{array}{l}\text { "Não, porque é } \\
\text { suja." }\end{array}$ & $\begin{array}{l}\text { "Sim, porque } \\
\text { não tem } \\
\text { substâncias que } \\
\text { são prejudiciais } \\
\text { a saúde." }\end{array}$ & $\begin{array}{l}\text { "Não, contém } \\
\text { substâncias que } \\
\text { prejudicam a } \\
\text { saúde." }\end{array}$ & $\begin{array}{l}\text { "Sim porque } \\
\text { podemos } \\
\text { purificala } \\
\text { fervendo" }\end{array}$ & $\begin{array}{l}\text { "não porque é } \\
\text { prejudicial para } \\
\text { a saúde." }\end{array}$ & $\begin{array}{l}\text { "Não porque o } \\
\text { sabão e uma } \\
\text { substancia } \\
\text { toxica." }\end{array}$ & $\begin{array}{l}\text { "não porque é } \\
\text { tóxico e prejudicial } \\
\text { para saúde." }\end{array}$ \\
\hline GRUPO 8 & $\begin{array}{l}\text { "Não. Por ser } \\
\text { terra e água, e } \\
\text { terra não ser } \\
\text { comestível." }\end{array}$ & $\begin{array}{l}\text { "Não. Porque é } \\
\text { muito forte, faz } \\
\text { mal a aúde e } \\
\text { tem grande } \\
\text { chance } \\
\text { morrer } \\
\text { hora." na } \\
\end{array}$ & $\begin{array}{l}\text { "Sim, se } 0 \\
\begin{array}{l}\text { corante for } \\
\text { comestível." }\end{array}\end{array}$ & $\begin{array}{l}\text { "Não. Faz mal } \\
\text { à saúde beber } \\
\text { areia (comer)." }\end{array}$ & $\begin{array}{l}\text { "Sim, porque é } \\
\text { água doce." }\end{array}$ & $\begin{array}{l}\text { "Não, porque } \\
\text { faz mal à } \\
\text { saúde." }\end{array}$ & $\begin{array}{l}\text { "Não. Porque faz } \\
\text { mal ao organismo. } \\
\text { Porque é ácido." }\end{array}$ \\
\hline
\end{tabular}

Fonte: Autores.

A quarta pergunta tinha por objetivo analisar se os alunos possuíam alguma noção sobre os diferentes métodos de purificação da água (Quadro 3). Até o momento, a classe ainda não havia sido apresentada formalmente a esse conteúdo, o qual foi trabalhado após o término de todas as atividades, sendo discutidos mais detalhadamente os métodos de filtração, decantação, fervura, destilação e adição de substâncias químicas. Em relação à primeira amostra, contendo terra, as respostas envolveram o uso de peneira (G2), embora o grupo tenha afirmado que ainda assim a água continuaria impura; fervura (G3, G4 e G7) e 
filtração/coação (G3, G4, G5 e G8). G5 apresentou ainda a proposta de um método de filtração caseira ("Com cascalho, terra, brita e areia") e G8 indicou um "filtro de pedra".

Em relação à segunda amostra, G1 e G5 não responderam; G2 e G6 afirmaram não haver necessidade de purificação; G3 e G4 afirmaram desconhecer algum método; G7 e G8 afirmaram não haver método possível (embora G8 tenha levantado a hipótese de fervura).

Quanto à terceira amostra, G4 e G8 afirmaram que não é necessária a purificação; G2, G3, G6 e G7 afirmaram que não é possível purificar a amostra. G1 e G5 não responderam à pergunta. Em relação à quarta amostra, as respostas foram mais diversificadas. Os grupos indicaram o uso de produtos para purificação (G1), peneira (G2 e G8) e fervura (G4, G6, G7). G3, G5 e G6 afirmaram que a purificação não é possível.

Na quinta amostra, G4 indicou a fervura. G1, G2, G3, G5, G6 e G8 indicaram que a amostra já está purificada. G7 respondeu apenas “não”, levando-nos questionar se para o grupo não há necessidade de purificação ou se o grupo não conhece algum método (consideramos a última opção, já que para o grupo a amostra contém álcool).

Na sexta amostra, G1 e G2 não responderam. G3 e G4 não souberam indicar uma resposta. G5, G6, G7 e G8 indicaram não ser possível purificá-la. Em relação à última amostra, G1, G2 e G5 não responderam. G3 e G8 afirmaram desconhecer algum método. G6 e G7 indicaram não haver nenhum método. G4, apesar de acreditar que havia água com sabão na garrafa, indicou a fervura como método adequado de purificação. 
Ensino, Saúde e Ambiente - V14 (1), pp. 01-27, ABR. 2021

Quadro 3 - Respostas à Pergunta 4.

\begin{tabular}{|c|c|c|c|c|c|c|c|}
\hline \multicolumn{8}{|c|}{ PERGUNTA 4: Como essa água poderia ser purificada? } \\
\hline & $\begin{array}{c}\text { ÁGUA + } \\
\text { TERRA }\end{array}$ & $\begin{array}{c}\text { ÁGUA + } \\
\text { ÁLCOOL }\end{array}$ & $\begin{array}{l}\text { ÁGUA DE } \\
\text { ALGÁRIO }\end{array}$ & $\begin{array}{l}\text { ÁGUA DE } \\
\text { UM AÇUDE }\end{array}$ & $\begin{array}{c}\text { ÁGUA } \\
\text { POTÁVEL } \\
\text { (TORNEIRA) }\end{array}$ & $\begin{array}{c}\text { ÁGUA + } \\
\text { VINAGRE }\end{array}$ & $\begin{array}{c}\text { ÁGUA + } \\
\text { DETERGENTE }\end{array}$ \\
\hline GRUPO 1 & & & & $\begin{array}{l}\text { "eu pegaria a } \\
\text { água colocaria } \\
\text { uma coisa pra } \\
\text { limpar as } \\
\text { sujeiras etc." }\end{array}$ & $\begin{array}{lll}\text { "ela já } & \text { é } \\
\text { purificada." } & \end{array}$ & & \\
\hline GRUPO 2 & $\begin{array}{l}\text { "Eu usaria uma } \\
\text { peneira, porque } \\
\text { a sujeira ficaria } \\
\text { na peneira, mas } \\
\text { a água ainda } \\
\text { ficaria suja." }\end{array}$ & 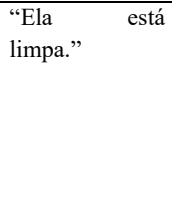 & $\begin{array}{l}\text { "Não tem como } \\
\text { purificar" }\end{array}$ & $\begin{array}{l}\text { "Pode ser em } \\
\text { uma peneira, } \\
\text { que a areia vai } \\
\text { ficar na } \\
\text { peneira." }\end{array}$ & "Ela está limpa." & & \\
\hline GRUPO 3 & $\begin{array}{l}\text { "esquentando e } \\
\text { coando." }\end{array}$ & "não sabemos." & $\begin{array}{ll} & \text { "não } \\
\text { como." } & \text { tem }\end{array}$ & $\begin{array}{l}\text { "Não temos } \\
\text { tecnologia para } \\
\text { isso." }\end{array}$ & $\begin{array}{l}\text { "Já } \\
\text { purificada" }\end{array}$ & "não sabemos" & "não sabemos" \\
\hline GRUPO 4 & "ferver e coar." & $\begin{array}{l}\text { "Não sei como } \\
\text { purificar." }\end{array}$ & $\begin{array}{lr}\text { "não } & \text { precisa } \\
\text { passar linpesa." }\end{array}$ & $\begin{array}{l}\text { "E so ferver } \\
\text { para purificar." }\end{array}$ & "so ferver" & $\begin{array}{l}\text { "Não sei como } \\
\text { purificar." }\end{array}$ & "É só ferver." \\
\hline GRUPO 5 & $\begin{array}{l}\text { "Com cascalho, } \\
\text { terra, brita e } \\
\text { areia." }\end{array}$ & & & $\begin{array}{l}\text { "não pode ser } \\
\text { purificada." }\end{array}$ & $\begin{array}{l}\text { "ela já é } \\
\text { tratada." }\end{array}$ & $\begin{array}{l}\text { "não pode ser } \\
\text { purificado." }\end{array}$ & \\
\hline GRUPO 6 & $\begin{array}{l}\text { "não, pois a cor } \\
\text { vai continuar a } \\
\text { mesma" }\end{array}$ & $\begin{array}{l}\text { "Esta } \\
\text { purificada." }\end{array}$ & $\begin{array}{l}\text { "não tem como } \\
\text { purificar" }\end{array}$ & $\begin{array}{l}\text { "não tem como } \\
\text { purificar" }\end{array}$ & $\begin{array}{l}\text { "Esta } \\
\text { purificada." }\end{array}$ & $\begin{array}{l}\text { "não tem como } \\
\text { purificar" }\end{array}$ & $\begin{array}{l}\text { "não tem como } \\
\text { purificar" }\end{array}$ \\
\hline GRUPO 7 & $\begin{array}{l}\text { "Fervendo, } \\
\text { matam os } \\
\text { micróbios." }\end{array}$ & $\begin{array}{l}\text { "Não, porque } \\
\text { ele } \quad \text { tem } \\
\text { substâncias que } \\
\text { usa alcool." }\end{array}$ & $\begin{array}{l}\text { "não porque é } \\
\text { detergente." }\end{array}$ & $\begin{array}{l}\text { "fervendo } \\
\text { porque mata os } \\
\text { germes." }\end{array}$ & “não." & $\begin{array}{ll}\text { "não } & \text { tem } \\
\text { como." } & \end{array}$ & "não tem como." \\
\hline GRUPO 8 & $\begin{array}{l}\text { "Filtrando e } \\
\text { também } \\
\text { coando os } \\
\text { pedacinhos de } \\
\text { pedra, fazendo } \\
\text { um filtro de } \\
\text { pedra." }\end{array}$ & $\begin{array}{lr}\text { "Na rinha } \\
\text { opinião não } \\
\text { tem como, mas } \\
\text { uma das } \\
\text { possibilidades } \\
\text { seria fervendo." }\end{array}$ & "Não precisa." & $\begin{array}{l}\text { "Passando pela } \\
\text { peneira } \\
\text { microscópica, } \\
\text { porque é muito } \\
\text { fininho, então } \\
\text { os grãos não } \\
\text { conseguem } \\
\text { cair." }\end{array}$ & "Não precisa." & $\begin{array}{l}\text { "Não é possível } \\
\text { purificar." }\end{array}$ & $\begin{array}{l}\text { "Não conhecemos } \\
\text { nenhum jeito de } \\
\text { purificar." }\end{array}$ \\
\hline
\end{tabular}

Fonte: Autores.

$\mathrm{Na}$ segunda etapa, os alunos puderam manusear as amostras, mas não as abrir. Isso possibilitou que alguns grupos revissem suas hipóteses anteriores, conforme o Quadro 4. G1 mudou suas ideias em relação à Garrafa 2, de água normal para vinagre, e à Garrafa 3, de água com lodo para corante verde. G2 e G7 também mudaram suas ideias sobre a Garrafa 3, passando de refrigerante e detergente para água com corante. Como esses grupos não apresentaram argumentos para sua mudança de posição, e considerando que o ato de manusear não justificaria tais mudanças, não descartamos que possa ter havido influência das ideias de um grupo sobre os outros. G6 mudou sua opinião sobre o conteúdo da Garrafa 2, passando de água para vinagre, utilizando como argumento o odor sentido da amostra. Apenas G1 e G7 indicaram mudanças nas respostas das outras perguntas, devido às mudanças nas suas respostas à primeira pergunta. 
Ensino, Saúde e Ambiente - V14 (1), pp. 01-27, ABR. 2021

Quadro 4 - Mudanças de opinião após o manuseio das amostras.

\begin{tabular}{|c|l|}
\hline \multirow{2}{*}{ GRUPO 1 } & Garrafa 2: "Na 2 achavamos que era água normal, mas depois descobrimos que era vinagre." \\
\cline { 2 - 3 } & $\begin{array}{l}\text { Garrafa 3: "Na garrafa 3, é uma garrafa com corante verde, e se for comestível o corante, dá pra tomar e pra } \\
\text { purificar, mas não sei como." }\end{array}$ \\
\hline GRUPO 2 & Garrafa 3: "Nós mudamos de ideia, achamos que seja água com corante." \\
\hline GRUPO 6 & Garrafa 2: "Na garrafa 2 a gente pensou que fosse água, mas é vinagre, porque o cheiro parece de vinagre." \\
\hline GRUPO 7 & $\begin{array}{l}\text { Garrafa 3: "Achamos que é água com corante verde. Da pra tomar se o corante não for tóxico. Não precisa purificar } \\
\text { se o corante não for tóxico." }\end{array}$ \\
\hline
\end{tabular}

Fonte: Autores.

Na terceira etapa da investigação, os alunos puderam abrir e cheirar as amostras para chegarem às suas respostas definitivas. O Quadro 5 mostra as últimas mudanças de opinião relatadas pelos grupos.

G2 mudou suas opiniões sobre a Garrafa 2 (passando de álcool para vinagre), a Garrafa 5 (vinagre para água) e Garrafa 7 (produto de limpeza para álcool). G3 mudou suas opiniões sobre a Garrafa 2 (passando de álcool para vinagre), a Garrafa 3 (refrigerante para água com corante) e G7 (água com sabão para álcool). G4 mudou suas opiniões sobre a Garrafa 3 (de suco de lima para água com corante) devido à ausência de odor esperado, e sobre a Garrafa 4 (vinagre para água do mar), devido à sua interpretação do odor sentido. G5 mudou suas opiniões sobre a Garrafa 4 (passando de vinagre para óleo vegetal) e Garrafa 7 (água com sabão ou detergente para álcool). G6 mudou sua opinião sobre a Garrafa 2 (passando de água para vinagre).

G8 mudou suas opiniões sobre o conteúdo das Garrafas 2 (passando de álcool para vinagre) e 7 (água com sabão para álcool), ambas por causa do odor sentido. Mudou sua opinião sobre a potabilidade da Garrafa 5, indicando a filtração como um método de purificação adequado antes de ingerir a água. G3, G4, G6 e G8 indicaram também mudanças nas respostas das outras perguntas, devido às mudanças nas suas respostas à primeira pergunta. 
Ensino, Saúde e Ambiente - V14 (1), pp. 01-27, ABR. 2021

Quadro 5 - Mudanças de opinião após se sentir o odor das amostras.

\begin{tabular}{|c|c|}
\hline \multirow{3}{*}{ GRUPO 2} & Garrafa 2: "A gente achava que era álcool, agora achamos que é vinagre." \\
\hline & Garrafa 5: "A gente achava que era vinagre, agora achamos que seja água." \\
\hline & Garrafa 7: “Achamos que é álcool.” \\
\hline \multirow{3}{*}{ GRUPO 3} & Garrafa 2: "É vinagre, se acha no mercado, da para por na comida, e não tem como purificar." \\
\hline & Garrafa 3: "É agua com corante, pega da pia, da para beber, não tem como purificar do corante." \\
\hline & Garrafa 7: “É alcol, se encontra no mercado, não é potável, não tem como purificar." \\
\hline \multirow{2}{*}{ GRUPO 4} & $\begin{array}{l}\text { Garrafa 3: "É algum corante, porque não tem cheiro. A origem é de alguma fábrica. potabilidade: não beberíamos. } \\
\text { como purificar: não sabemos." }\end{array}$ \\
\hline & Garrafa 4: "é água do mar por causa do cheiro" \\
\hline \multirow[t]{2}{*}{ GRUPO 5} & Garrafa 4: "É óleo vegetal." \\
\hline & Garrafa 7: “É álcool." \\
\hline GRUPO 6 & Garrafa 2: "É vinagre, e vem da garrafa de vinagre. Não da pra tomar, só se for na salada. Não tem como filtrar. \\
\hline \multirow{3}{*}{ GRUPO 8} & $\begin{array}{l}\text { Garrafa 2: "É vinagre. Pq tem odor muito forte. Vem do mercado. Pq é encontrado lá. Não faz bem pra saúde, então } \\
\text { não é bom tomar. Não é possível purificar." }\end{array}$ \\
\hline & Garrafa 5: "Mudamos de ideia sobre potabilidade. Dá pra tomar, se estiver filtrada." \\
\hline & $\begin{array}{l}\text { Garrafa 7: "Vimos que é álcool. Pelo cheiro. Vem do mercado. Não dá pra tomar. Faz mal a saúde. Não é possível } \\
\text { purificar." }\end{array}$ \\
\hline
\end{tabular}

Fonte: Autores.

O desenrolar de toda a atividade permitiu que os alunos desenvolvessem aspectos relacionados à argumentação científica, habilidade que tem sido considerada relevante nas perspectivas inovadoras de ensino. A utilização de evidências para defender e confrontar pontos de vista com os dos colegas permite o desenvolvimento do pensamento crítico (JIMÉNEZ-ALEIXANDRE; ERDURAN, 2008).

A argumentação oferece oportunidades para que os estudantes possuam construir socialmente o conhecimento (BAKER, 2009). A interpretação de evidências na investigação possibilita o envolvimento em discussões com os colegas, a ponderação de diferentes fontes de informação e a consideração de outros pontos de vista (JIMÉNEZ-ALEIXANDRE; ERDURAN, 2008). Ao avançarem nas novas formas de avaliação das amostras, os grupos puderam reconsiderar e modificar opiniões anteriores, o que é essencial para uma compreensão correta do pensamento científico.

\section{g) Atividade investigativa 2: pH da água}

Uma vez que os alunos ainda não haviam sido apresentados formalmente aos conceitos de acidez, basicidade e $\mathrm{pH}$, a segunda atividade investigativa procurou levar os grupos a exercerem a capacidade de observação (ao perceberem e registrarem as mudanças de cor nas amostras) e a desenvolver uma explicação sobre o que poderia ter levado ao 
surgimento das diversas cores, uma vez que todas as amostras haviam recebido o mesmo indicador de repolho roxo (Figura 2).

A utilização do repolho roxo como indicador de $\mathrm{pH}$ ocorre devido à presença de substâncias chamadas antocianinas, presentes em suas folhas. Em água $(\mathrm{pH}$ neutro $=7)$ esse indicador tem coloração roxa, mas apresenta colorações vermelha e púrpura em soluções ácidas $(\mathrm{pH}<7)$ e verde, azul, verde e amarela em soluções básicas ( $\mathrm{pH}>7)$ (GOUVEIAMATOS, 1999).

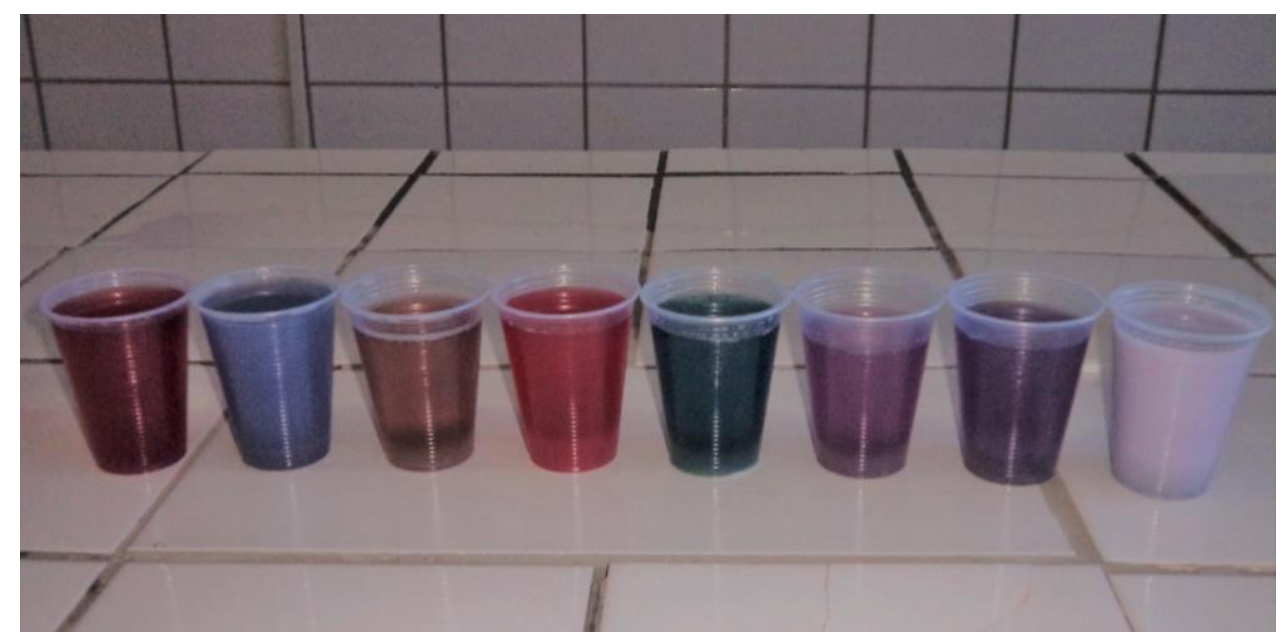

Figura 2 - Amostras usadas na atividade investigativa do pH da água (da esquerda para a direita: vinagre branco, água sanitária, detergente, suco de limão, bicarbonato de sódio, álcool, soda cáustica e leite), após a adição do extrato de repolho roxo.

Fonte: Autores.

A maioria dos grupos forneceu uma explicação geral para o surgimento das cores através de uma "mistura de substâncias". Assim, "as misturas dos ingredientes foi o que produziu as cores diferentes" (G2); "com a mistura deve ter acontecido alguma reação química e mudou as suas cores" (G8); "aconteceu uma mistura das substâncias que estavam naqueles copos mais o repolho roxo" (G1) e "isso aconteceu porque as pigmentações das substâncias se misturaram" (G6).

G3 explicou as mudanças com base em uma capacidade de "absorção de cor" do repolho pelas amostras. Na tentativa de criar uma escala, afirmaram que "os copos que ficaram rosa não absorveram bem a cor, os que ficaram verde absorveram mais e os que ficaram vermelho são os que absorveram mais ou menos".

G5 forneceu algumas explicações diferentes. Procurando de alguma forma incorporar conceitos prévios aprendidos em aula, explicou que "as cores mais claras indicam que tem substâncias mais densas, e as mais escuras menos densas". Explicou também, isoladamente, 
que a amostra 5 (com bicarbonato de sódio) mudou de cor "por causa do sódio, que deve ter reagido com o repolho".

G4 e G7 relataram as mudanças de cor, mas não conseguiram criar nenhuma hipótese explicativa. Na aula seguinte, o professor realizou com os alunos uma explicação a respeito do conceito de $\mathrm{pH}$. Uma vez que tal conceito engloba muitas definições que ainda não foram aprendidas pelos alunos, procurou-se realizar uma transposição didática do assunto, limitando a profundidade conceitual e a linguagem empregada na exposição (CHEVALLARD, 1998). Retornou-se novamente ao contexto do desenho apresentado. Relembramos aos alunos que no começo do episódio, Bart e Lisa estavam pescando em um ambiente aparentemente saudável, com água que parecia pura. Mas aquela água possuía elementos contaminantes invisíveis a olho nu. Assim, a potabilidade não pode ser baseada apenas na aparência ou transparência da amostra, mas deve passar por rigorosos testes a fim de determinar sua qualidade e pureza.

Tanto essa atividade como a atividade prévia procuraram envolver os alunos na prática da "argumentação colaborativa". Essa desempenha um papel fundamental na ciência, que avança não pela acumulação de fatos, mas por debate e argumentação. Os professores devem apresentar aos estudantes dificuldades para serem trabalhadas individualmente ou em grupo, sugerindo que utilizem dados para justificarem as suas hipóteses. Esta forma de aprendizagem implica a utilização de determinadas capacidades cognitivas como analisar, comparar, deduzir, inferir e valorar, além de descrever, definir, explicar, justificar, argumentar e demonstrar (COSTA, 2008).

A Educação Ambiental deve promover uma nova forma de desenvolvimento sustentável, em uma dimensão transformadora e coletiva. Os alunos devem ser capazes de identificar os problemas ambientais causados pela ação humana e os possíveis riscos da extinção de espécies, bem como perceber a importância de se preservar o meio ambiente. Compreender a temática da sustentabilidade é refletir sobre o tipo de desenvolvimento que a sociedade contemporânea está passando, e assim entender os reflexos dessas interferências, de forma direta e indireta, do homem sobre a natureza (JACOBI, 2003).

O professor pode utilizar o contexto da sala de aula para a utilização de metodologias que possibilitem por parte do aluno a realização de procedimentos e reflexões. Estes não devem ser apenas expositivos ou informativos, mas devem fornecer aos estudantes meios para que formulem suas próprias opiniões e argumentos, possibilitando o seu desenvolvimento nas esferas moral e intelectual.

Rosa (2000) aponta que algumas atividades relacionadas ao ensino de Ciências saem fortemente melhoradas com o uso dos recursos audiovisuais, podendo ser empregados com as funções de motivar, demonstrar, simular, dar apoio ao professor, ser um organizador prévio e 
provocar a diferenciação progressiva ou a reconciliação integrativa, estando as três últimas funções relacionadas à Teoria de Aprendizagem de Ausubel.

Porém, Silva (2006), citando diversos autores, assevera que as imagens fornecidas por diversos recursos didáticos são pouco exploradas na sala de aula, o que permite inferir que boa parte dos professores considera que as imagens falem por si ou "transmitam" um único sentido. Mas assim como o professor sente-se livre para interferir em um texto escrito, modificando-o ou acrescentando novos dados, interpretações e contextos mais próximos do aluno, assim ele deve também fazer com o vídeo (MORÁN, 1995). A utilização dos recursos audiovisuais permite a criação de um novo meio de ajudar a (re)construção do conhecimento (LEÃO, 2004). Essa forma de expressão pode gerar elementos de motivação para novas situações, conduzindo à criticidade no espectador (SALINAS, 1988).

Um aprendizado significativo ocorre quando os alunos recebem a proposta de aprender de uma forma mais interativa e divertida. O seu entusiasmo com a forma aparente de atividade lúdica facilita a apropriação e a aprendizagem significativa de conhecimentos (CAMPOS et al., 2003). Os desenhos animados são a preferência das crianças dentro da grade televisiva. A escola precisa estar inteirada das linguagens da sociedade informatizada e tecnológica em que está inserida, procurando estabelecer junto aos alunos abordagens que apresentem pontos de contato com o mundo imagético (CITELLI, 2004).

Gomes e colaboradores (2012) destacam que os desenhos animados promovem o encantamento no aluno pelo seu uso de imagens sequenciais, cores, sons e situações vivenciadas pelos personagens. Funcionam assim como um recurso atrativo, envolvendo uma gama de alternativas que podem ser trabalhadas pelo professor na sala de aula, relacionandose com a formação de uma consciência crítica ao incentivar o educando a realizar uma investigação sobre o que lhe está sendo apresentado.

A utilização dos desenhos animados no processo de ensino-aprendizagem alia o aspecto lúdico ao questionamento. O questionamento acontece tanto para os estudantes, ao quais são instigados a relacionar as informações teóricas aprendidas em aula com as situações apresentadas nos desenhos, quanto para o professor, que se sente estimulado a revisar suas formas de aquisição e transmissão do conhecimento (normalmente ligada aos livros didáticos), o que pode gerar uma mudança em sua própria postura em sala de aula (MESQUITA; SOARES, 2008).

Assim, a presente proposta não pretendeu negligenciar, mas sim integrar formas diversas de trabalho, como discussões em pequenos grupos, aulas dialogadas, pesquisa e atividades investigativas, partindo do desenho animado assistido como gerador do contexto para a sequência didática. Pretendemos oferecer sugestões aos professores, colaborando na 
construção de um conhecimento científico pertinente e da reflexão social por parte de nossos alunos.

\section{CONSIDERAÇÕES FINAIS}

Os professores de Ciências da Natureza e disciplinas relacionadas têm sido cada vez mais forçados a repensarem suas práticas pedagógicas, buscando meios de renovar as formas de contextualização para motivar o aluno no estudo das ciências (DELIZOICOV; ANGOTTI; PERNAMBUCO, 2007). Como afirmou Cortella,

uma nova qualidade social exige uma reorientação curricular que preveja levar em conta a realidade do aluno. Levar em conta não significa aceitar essa realidade, mas dela partir; partir do universo do aluno para que ele consiga compreendê-lo e modificá-lo. (CORTELLA, 2004, p. 16)

O uso das mídias possibilita a criação de situações de aprendizagem diversificadas, nas quais o professor desenvolve o papel de mediador da interação dos alunos com os objetos do conhecimento. A televisão se dirige a esquemas mentais, capacidades cognitivas, estruturas perceptivas e sensibilidades já presentes nas pessoas, o que facilita a sua utilização em contextos educativos, otimizando o processo ensino-aprendizagem (FERRÉS, 1996).

A mídia tem assumido um importante significado na configuração do repertório imaginativo das crianças. Ela faz isso ao oferecer referências simbólicas, narrativas e valores estéticos (SALGADO; PEREIRA; SOUZA, 2006). Procuramos demonstrar como os vídeos podem ser utilizados como recursos geradores de aprendizagem, realizando a proposição de outras atividades agregadas, no processo de ensino-aprendizagem.

A utilização do episódio de um desenho animado como uma estratégia pedagógica para o ensino de Educação Ambiental na disciplina de Ciências demonstrou-se uma ferramenta motivadora. Ela possibilitou a reflexão acerca dos diversos impactos e riscos associados à intervenção do homem sobre o ambiente em que está inserido. Instigou os alunos a questionarem-se sobre os processos de impactos ambientais e suas consequências, em especial sobre a qualidade da água, e os levou a visualizarem seu papel como agentes responsáveis por uma atitude sustentável e ética frente aos desenvolvimentos sociais. 


\section{REFERÊNCIAS}

ALVES, M. A. Filmes na Escola: Uma abordagem sobre o uso de audiovisuais (vídeo, cinema e programas de TV) nas aulas de Sociologia do Ensino Médio. 2001. 154 p.

Dissertação (Mestrado em Educação) - Faculdade de Educação, Universidade Estadual de Campinas, Campinas, 2001.

ARROIO, A.; GIORDAN, M. O Vídeo Educativo: Aspectos da Organização do Ensino. Química Nova na Escola, v. 24, p. 8-11, 2006.

BAKER, M. Argumentative interactions and the social construction of knowledge. In: MIRZA, N. M., PERRET-CLERMONT, A. N. (Orgs). Argumentation and Education: Theoretical Foundations and Practices. New York: Springer, 2009. p. 127-144.

BETTI, M. Mídias: aliadas ou inimigas da educação física escolar? Motriz, v. 7, n. 2, p. 125129, 2001.

BORNHEIM, G. A temática ambiental na sociedade contemporânea. Revista Educação: teoria e prática, Rio Claro, v. 9, n. 16/17, p. 1-9, 2001.

BOSELLI, S. M. C. Desenho Animado Infantil: Um caminho da Educação a Distância. 2002. 74 p. Dissertação (Mestrado em Engenharia de Produção, Área de Concentração Mídia e Conhecimento), Programa de Pós-Graduação em Engenharia de Produção, Universidade Federal de Santa Catarina, Florianópolis, 2002.

CAMPOS, L. M. L.; FELICIO, A. K. C.; BORTOLOTTO, T. M. A produção de jogos didáticos para o ensino de Ciências e Biologia: uma proposta para favorecer a aprendizagem. Caderno dos Núcleos de Ensino, p. 35-48, 2003.

CHAMPANGNATTE, D. M. O.; NUNES, L. C. A inserção das mídias audiovisuais no contexto escolar. Educação em Revista, v. 27, n. 3, p. 15-38, 2011.

CHEVALLARD, Y. La Transposición Didáctica: del saber sabio al saber enseñado. La Pensée Sauvage, Argentina, 1998.

CITELLI, A. (Org.). Outras linguagens na escola: publicidade, cinema e TV, rádio, jogos, informática. 4. ed. São Paulo: Cortez, 2004.

CORCORAN, E.; NELLEMANN, C.; BAKER, E.; BOS, R.; OSBORN, D.; SAVELLI, H. (Eds). Sick Water? The central role of wastewater management in sustainable development. A Rapid Response Assessment. United Nations Environment Programme, UN-HABITAT, GRID-Arendal. 2010. Disponível em: <goo.gl/tjasRN>. Último acesso em: 29 mar. 2018.

CORTELLA, M. S. A escola e o conhecimento: Fundamentos epistemológicos e políticos. 8. ed. São Paulo: Cortez, 2004.

COSTA A. Desenvolver a capacidade de argumentação dos estudantes: um objectivo pedagógico fundamental. Revista Iberoamericana de Educación, v. 46, n. 5, p. 1-8, 2008.

DELIZOICOV, D.; ANGOTTI, J. A.; PERNAMBUCO, M. M. Ensino de Ciências:

Fundamentos e métodos. São Paulo: Cortez, 2007. 
EXAME. TV é o dispositivo mais usado entre crianças e adolescentes. 2012. Disponível em: <goo.gl/W1mCje>. Último acesso em: 10 abr. 2018.

FERRÉS, J. Televisão e Educação. Porto Alegre: Artes Médicas, 1996. 180 p.

GEPEQ (Grupo de Pesquisa em Educação Química, Laboratório aberto, Instituto de Química - USP, B7 - superior, São Paulo - SP). Estudando o Equilíbrio Ácido $\rightleftharpoons$ Base. Química Nova na Escola, n. 1., p. 32-33, 1995.

GOMES, M. P.; MACHADO, M. T. C.; MANHÃES, A. C. T. S.; SANTOS, T. S.; SOARES R. A. R. Desenho animado: recurso pedagógico no processo ensino-aprendizagem de educação ambiental. Ensino, Saúde e Ambiente, v. 5, n. 2, p. 90-101, 2012.

GOUVEIA-MATOS, J. A. M. Mudanças nas cores dos extratos de flores e do repolho roxo. Química Nova na Escola, n. 10, p. 6-10, 1999.

GUIMARÃES, C. C.; GONÇALVES, E. S. Uma reflexão sobre o papel da internet na prática da Pesquisa Escolar. In: IX ENCONTRO NACIONAL DE PESQUISA EM EDUCAÇÃO EM CIÊNCIAS - IX ENPEC, 2013. Águas de Lindóia, SP. Atas... ABRAPEC, 2013. p. 1-8.

HALPERN, P. Os Simpsons e a Ciência: o que eles podem nos ensinar sobre física, robótica, vida e universo. 1. ed. São Paulo: Novo Conceito, 2008.

JACOBI, P. Educação ambiental, cidadania e sustentabilidade. Cadernos de Pesquisa, Fundação Carlos Chagas, v. 113, p. 189-205, 2003.

JIMÉNEZ-ALEIXANDRE, M. P.; ERDURAN, S. Argumentation in Science Education: an Overview. In: ERDURAN, S.; JIMÉNEZ-ALEIXANDRE, M. P. (Ed.). Argumentation in science education: perspectives from classroom-based research. Dordrecht: Springer, 2008. p. 3-27.

LEÃO, M. B. C. Multiambientes de aprendizaje en entornos semipresenciales. Pixel-Bit Médios y Educación, v. 23, p. 65-68, 2004.

MELO, W. C.; HOSOUME, Y. O jornal em sala de aula: uma proposta de utilização. In: SIMPÓSIO NACIONAL DE ENSINO DE FÍSICA, 15., 2003. Anais... Curitiba, PR: Ed. Paraná, 2007. p. 154.

MESQUITA, N. A. S.; SOARES, M. H. F. B. Visões de ciência em desenhos animados: uma alternativa para o debate sobre a construção do conhecimento científico em sala de aula.

Ciência e Educação, v. 14, n. 3, p. 417-429, 2008.

MORÁN, J. M. Internet no Ensino. Comunicação e Educação, v. 14, p. 17-26, 1999.

MORÁN, J. M. O Vídeo na Sala de Aula. Comunicação e Educação, v. 2, p. 27-35, 1995.

NICOLETTI, E. R. Explorando o tema água através de diferentes abordagens metodológicas no Ensino Fundamental. 2013. 94 f. Dissertação (Mestrado em Educação em Ciências: Química da Vida e Saúde) - Universidade Federal de Santa Maria, Santa Maria, 2013.

OROZCO-GÓMEZ, G. Professores e meios de comunicação: desafios, estereótipos e pesquisas. Comunicação \& Educação, n. 10, p. 57-68, 1997. 
PIMENTA, S. M.; BOAVENTURA, G. R.; PEÑA, A. P.; RIBEIRO, T. G. Estudo da qualidade da água por meio de bioindicadores bentônicos em córregos da área rural e urbana. Revista Ambiente \& Água, v. 11, n. 1, p. 198-210, 2015.

RAZERA, J. C. C.; NARDI, R. Ética No Ensino de Ciências: Responsabilidades e Compromissos com a Evolução Moral da Criança nas Discussões de Assuntos Controvertidos. Investigações em Ensino de Ciências, v. 11, n. 1, p. 53-66, 2006.

ROCHA, M. B. Contribuições dos textos de divulgação científica para o ensino de Ciências na perspectiva dos professores. Acta Scientiae, v. 14, n. 1, p. 132-150, 2012.

ROSA, P. R. S. O uso dos recursos audiovisuais e o ensino de ciências. Caderno Brasileiro de Ensino de Física, v. 17, n. 1, p. 33-49, 2000.

SALGADO, R. G.; PEREIRA, R. M. R.; JOBIN e SOUZA, S. Da recepção à produção de mídia: as crianças, a cultura e a educação. Revista Alceu, v. 7, n. 13, p. 165-181, 2006.

SALINAS, J. Interactividad y diseño de vídeos didácticos. Comunicación presentada al Interactive Video in Schools Seminar. Irlanda del Norte: Universidad de las Islas Baleares. 1988.

SILVA, H. C. et al. Cautela ao usar imagens em aulas de ciências. Ciência \& Educação, v. 12, n. 2, p. 219-233, 2006.

SLAVIN, R. E. Using Student Team Learning. Baltimore: Johns Hopkins University, 1994.

SOBRE OS AUTORES

\section{AUTOR 1.}

Professor no Instituto Federal de Educação, Ciência e Tecnologia Sul-Riograndense, Campus Visconde da Graça - CaVG (Pelotas - RS). Coordenador do Curso Superior de Licenciatura em Ciências Biológicas e da Área de Biologia, na mesma instituição. Doutor em Educação em Ciências: Química da Vida e Saúde, pela Universidade Federal de Santa Maria (UFSM). Mestre em Ciências Biológicas: Bioquímica Toxicológica (UFSM). Bacharel e Licenciado em Ciências Biológicas (UFSM).

\section{AUTORA 2.}

Professora adjunta da Universidade Federal de Santa Maria (UFSM), Departamento de Ecologia e Evolução, atuando no ensino de Genética Geral, Genética Humana, Biologia Molecular e Evolução, junto aos cursos de Ciências Biológicas e Medicina. Coordenadora e orientadora no PPG Educação em Ciências: Química da Vida e Saúde (UFSM). Doutora em Educação em Ciências: Química da Vida e Saúde (UFSM). Mestre em Genética e Biologia Molecular pela Universidade Federal do Rio Grande do Sul (UFRGS). Graduada em Ciências Biológicas (UFSM).

\section{Submetido em 30/10/2019}

Aprovado em 30/04/2021

Publicado em 30/04/2021 